\title{
What makes collaborative water governance partnerships resilient to policy change? A comparative study of two cases in Ecuador
}

\author{
$\underline{\text { Paúl Cisneros }}^{1}$
}

\begin{abstract}
The Sustainable Development Goals (SDGs) related to water and sanitation mandate the implementation of collaborative approaches to water governance to secure water for all by 2030. The implementation of collaborative governance requires the adoption of supportive regulations, resources, and the development of capable public sector institutions. In recent years, several countries in Latin America have introduced reforms to their water codes to promote collaborative water governance. However, our knowledge of the outcomes of these reforms is still in its infancy, in particular on how they influence the evolution of existing governance initiatives. In this paper, I study how collaborative water governance initiatives in Ecuador responded to the introduction of new regulations for stakeholder participation in watershed councils. Our findings show that network structures respond in different ways to policy change. In a context where regulations limit the participation of NGOs in watershed committees, the network with higher dependency to external resources was incapable of adjusting. On the other hand, the key elements that helped the resilient network navigate policy change were the existence of high levels of trust, the availability of resources to subsidize participation, the ability to connect the local structure to other networks, and high levels of perceived legitimacy. Governments and international donors interested in SDG 6 should consider these elements to design and implement strategies to promote collaborative management in regions where initiatives already exist. Failure to do so may cause weaker structures to disappear, and discourage actors from future participation, increasing the costs of putting collaborative structures in place and leaving inequalities untackled.
\end{abstract}

Key Words: Ecuador; policy change; resilience; social networks; water governance

\section{INTRODUCTION}

Between 2005 and 2015 most Latin American countries reformed their national water codes. Despite differences in the political orientations of the regimes that implemented such reforms, the overarching objective was to reverse, at least partially, the policies adopted in the 1990s. In general, these reforms restructured public sector organizations to give the state a more central role in water governance. The reforms also mandate the adoption of the participatory watershed approach and new policy tools to improve the social and environmental aspects of water governance (Embid and Martín 2015). To this date, there is relatively little knowledge about these reforms, in particular on how they shape interactions between the stakeholders of water governance. A better understanding of how regulations on stakeholder participation influence governance, is essential to inform undergoing efforts to design and implement policies inspired in Agenda 2030 and the Sustainable Development Goals. It is of particular importance for Goal 6 that mandates the adoption of participatory approaches for water governance by 2030 (see https://goo.gl/YniHDh). In this paper, I study the different reactions that watershed governance partnerships in Ecuador had to the introduction of regulations on stakeholder participation between 2015 and 2017.

Recent changes in natural resources management policies in Latin America are in line with the growing criticisms of the free market doctrine adopted at a global scale during the 1990s (Arrow et al. 2014). These criticisms highlight the influence of the privatization of water provision and administrative fragmentation on deepening existing inequalities (Castro 2007, Wollmann 2015). In the past decade and a half, the region experienced growth of demands for a renewed involvement of the State in the direct provision of services and the implementation of water policy. One key challenge states faced to meet these demands was the creation of public sector organizations capable of promoting meaningful stakeholder participation in decision making in a context of high political and policy volatility (Eakin and Lemos 2006, Falleti 2010, Peruzzotti 2017). These characteristics make Latin America an exciting place to study how changes in regulations affect the evolution of stakeholder participation in natural resources governance, an aspect often overlooked in the dominant literature about Europe and the United States (Pahl-Wostl et al. 2008, Henry and Vollan 2014).

In this paper I draw from the social relational approach developed by Bodin and others, which examines how relational individuals and the structures their interactions give rise to influence natural resource governance (Bodin et al. 2006, 2011). I focus on how the pattern and structure of the interactions within water governance partnerships influence the capacity of those structures to overcome an external disturbance, such as the introduction of regulations on stakeholder participation. I chose to study water partnerships in Ecuador because this country launched an ambitious implementation plan of its new regulations on water governance in 2015, which aimed at creating at least 20 participatory watershed councils before the end of 2016. Also, studies in international comparative law commend Ecuador's water code as one of the most comprehensive in the region regarding the mechanisms for stakeholder participation (Embid and Martín 2015). More importantly, by comparing a successful case of adjusting to regulatory changes with an unsuccessful case, this paper informs decision makers of the dangers of implementing regulations that homogenize stakeholder participation across watersheds and other natural resource governance units. 


\section{CONCEPTUAL FRAMEWORK}

The contemporary approaches to participatory and collaborative watershed governance emerged in Europe and the United States in the 1970 s as a response to the limitations of command-andcontrol approaches to managing problems such as nonpoint source pollution and habitat degradation (Sabatier et al. 2005a, Grigg 2016). Scholarly studies of this mainstream approach to water governance and planning emerged in the 1990s and are part of a growing literature on the democratic and sustainable governance of the commons (Pahl-Wostl et al. 2007, Engle et al. 2011). A significant limitation of this literature originates in the lack of discussion about the varying political support for these new forms of governance. The pervasive idea in the literature is that such support remains constant or even increases over time and at the same rate across different political systems (e.g., Armitage and Plummer 2010, Boyd and Folke 2012, Pahl-Wostl et al. 2012, Henry and Vollan 2014, Mosello 2015, Fliervoet et al. 2016). Thus, the influence of unstable political and policy contexts on participative forms of governance, such as Latin America, remains largely understudied (see Brown 2015).

In the early 1990s, Latin American countries adopted public policies inspired by the so-called Washington Consensus introducing forms of governance that reduced the role for the State in providing public services and fragmented public management (Grindle 2000). At the same time, social participation in public affairs was actively promoted as a means to improve the effectiveness of the democratic systems and to prevent a backslide into the authoritarian regimes of decades past (Tulchin and Selee 2004). It was in this context that participatory watershed governance became a significant, and largely unregulated, policy tool and where the first participatory water management initiatives emerged (Tortajada 2001, Abers 2007).

With the upsurge of political movements critical of neoliberalism in the early 2000 s, several countries adopted centralized forms of governance that put the state back in the center of public action (Grugel and Riggirozzi 2009). Several authors agree that these regimes privileged central planning over securing the involvement of local stakeholders in natural resources governance (see Tockman and Cameron 2014). It was in this context that the most recent wave of reforms to water codes occurred. Studies of the centralist reforms of the previous decade could shed light on how collaborative governance initiatives may respond to the next wave of changes in the policy regimes of the region. As I write this article, some Latin American countries are adopting or deepening policies akin to those of the Washington Consensus era (see Lansberg-Rodríguez 2016).

The adoption of new policy paradigms influences the structures and performance of policy subsystems such as collaborative watershed partnerships (Sabatier 1988, Howlett and Ramesh 1998). However, the direction and intensity of change are influenced by the different patterns of relations that give structure to the subsystems (Bodin et al. 2011). Social network analysis (SNA) provides several tools to evaluate how the attributes of stakeholder organizations in collaborative governance initiatives, as well as the structural characteristics of the relationships among them, shape their reaction to external disturbances such as policy change. In SNA, graphs or sociograms are used to represent social networks, and their properties are analyzed using mathematical procedures (Butts 2008). In this paper, I combine SNA with qualitative content analysis using a conceptual framework inspired by previous work on natural resources governance developed by Sabatier et al. (2005b) and Carlsson and Sandström (Sandström 2008, Sandström and Carlsson 2008).

The main idea of this framework is that the structural characteristics of networks influence collaborative outputs and outcomes. Figure 1 shows the four components of the framework. First, drawing from Sabatier et al. (2005b), the framework highlights variables that make up the context in which watershed partnerships operate, such as socioeconomic conditions or decisions made in other subsystems. In this case, I am interested in policy change as the primary external factor influencing change in watershed partnerships. Based on Sabatier and Mazmanian (1980), I understand policy change as a change in legislation that seeks to alter the composition of a policy subsystem, regarding actors and resources, and the outputs and outcomes it produces.

Fig. 1. Conceptual framework.

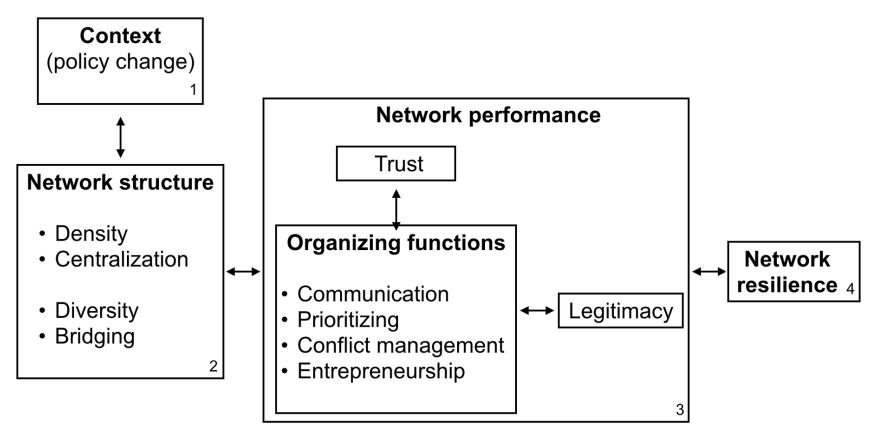

Second, policy changes are translated into actionable ideas and strategies by the network structure of each partnership. I am particularly interested in how well connected and how diverse networks are (see Sandström and Carlsson 2008, Sandström and Rova 2010). Connectivity relates to the density and the centralization of the network, while diversity relates to the attributes of the entities that compose the network and their connections to other networks.

These properties influence the third component or network performance. Performance includes three elements: trust, organizing functions, and legitimacy. Trust is the expectation that an individual has of the behavior of other stakeholders in a collaborative partnership. Individuals form their expectations based on assessments of three trust warranting properties: promise-keeping, value similarity, and technical competence (Lubell 2007). According to Sabatier et al. (2005c), trust is the primary resource produced by relational networks and the promotor of collective action. The level of trust in a network affects the quality of the internal and external bargaining processes, what I call organizing functions (Carlsson and Sandström 2008, Sandström and Carlsson 2008). The framework considers four organizing functions: communication, prioritizing, conflict management, and entrepreneurship (Sabatier et al. 2005b, Boin and Lodge 2016). The literature of adaptive institutions highlights these functions as critical elements that influence the production of resilience in social-ecological systems (Boyd and 
Folke 2012, Koontz et al. 2015) and I describe them in more detail in the next section. The performance of the organizing functions shapes the partnership's legitimacy or the evaluations that actors make of the partnership's performance considering procedural and substantive aspects (Lubell 2007).

The fourth component of the framework is resilience. I understand resilience as an outcome of collaborative governance initiatives, and it refers to the capacity of a system to absorb disturbances and reorganize while changing to retain substantially the same function, structure, identity, and feedbacks (Walker et al. 2004).

\section{Connectivity and performance}

Prell (2012) argues that when network density and centralization are relatively high, communication within the network improves. High density or a high number of interactions between the members of a system is essential to distribute resources to more actors within the system. Information is a critical resource in contexts of regulatory uncertainty, and its effective distribution could promote a better understanding of the characteristics and potential effects of policy change. However, a dense network could also suggest a system with low levels of trust among actors. If actors cannot confidently predict if others will honor their compromises to the collaborative initiative they may establish additional relationships to monitor the behavior of partners (Sabatier et al. 2005b). Thus, when investigating how density influences communication in a social network, it is essential to consider the existing levels of trust. I formulate hypothesis 1 to account for this dynamic:

H1: Networks for collaborative watershed governance with higher density and higher levels of trust will show improved internal communication about a policy change.

Responding to external changes depends on the capacity that entities in a network have to coordinate actions. One key aspect of coordinated action is prioritization. Several authors argue that high centralization allows network actors to prioritize among many policy objectives and to identify the means to achieve them because relevant information may be "relayed and synthesized to a few actors who can make a decision and take action" (Leavitt 1951, as cited in Bodin et al. 2006). Centralization describes the extent to which a network organizes around specific nodes (Scott 2000). A centralized network will exhibit a few actors participating from a high proportion of the connections in the network. In contexts of low trust, high centralization could undermine the flow of resources to some regions of the network. This dynamic may result in the emergence of communities with opposed policy objectives and the emergence of intractable conflicts. I formulate hypothesis 2 to study this dynamic:

$\mathrm{H} 2$ : Networks for collaborative watershed governance with higher levels of centralization and trust will perform better at prioritizing.

\section{Diversity, bridging, and performance}

Some authors have found associations between high diversity and effective resource mobilization (Folke et al. 2005, Bodin et al. 2006). In principle, the participation of actors with different organizational backgrounds provides partnerships with a set of resources to tackle a wide array of problems (Carlsson and Sandström 2008). However, actors with the same organizational background may differ in policy-oriented beliefs and form interorganizational coalitions to pursue rivaling policy objectives, especially in contexts of low trust (Sabatier 1988, Sewell 2005, Heinmiller and Pirak 2017). Thus, it is essential to determine if diverse networks manage internal conflicts effectively improving its capacity to mobilize resources. To account for these dynamics, I formulate hypothesis 3 :

H3: Networks for collaborative watershed governance with higher diversity and more effective conflict-management capabilities will show improved resource mobilization.

Some actors establish bridges across networks providing their local structures with greater access to novel resources that facilitate policy innovation (Carlsson and Sandström 2008, Prell 2012). The number and the redundancy of the connections to other structures facilitate the mobilization of social memory or knowledge across networks, both critical elements for policy innovation and resilience (Folke et al. 2005, Bodin et al. 2006). Innovative systems perform entrepreneurial actions such as monitoring the political and policy environment, gathering information to reduce uncertainty in decision making, and developing connections with decision-making venues to facilitate policy-oriented action (Janssen et al. 2006, Mintrom and Norman 2009). The first two entrepreneurial actions seek to increase the collective knowledge base available for decision making (Folke et al. 2005). The latter is related to the need for gathering support from actors with similar policy objectives to reduce institutional constraints for action or increase the availability of resources (Nohrstedt 2011). Hypothesis 4 is formulated to assess these dynamics:

H4: Networks for collaborative watershed governance with more and more redundant connections to other networks will show improved entrepreneurship.

\section{Organizing functions, legitimacy, and resilience}

If actors believe the partnership functions well and that it produces positive effects on the watershed, they will be more likely to continue investing in collaboration, thus making the partnership more readily prepared to face external perturbations (Lubell et al. 2005). Therefore, actors in a legitimate partnership should be able to decide to maintain or change essential functions based on their understanding of the characteristics and potential effects of policy change. Hypotheses 5 is formulated to assess these interactions:

H5: Networks for collaborative watershed governance with improved performance and high perceived legitimacy will produce controlled transformations that maintain their primary functions upon policy changes.

\section{METHODS}

In this paper, I study the two collaborative water governance partnerships that existed in Ecuador between 2014 and 2017. Figure 2 shows the location of the study sites. Other collaborative partnerships existed before 2014 but ceased activities because of different combinations of the following factors: lack of funding (Barrera et al. 2010), the uncertainty produced by the reform of the water law that extended for over six years (2008-2014; Poats 2017), and limited political support by key stakeholders (E30). These variables also influenced the production of resilience in the partnerships I study. 
Fig. 2. Location of the study sites.

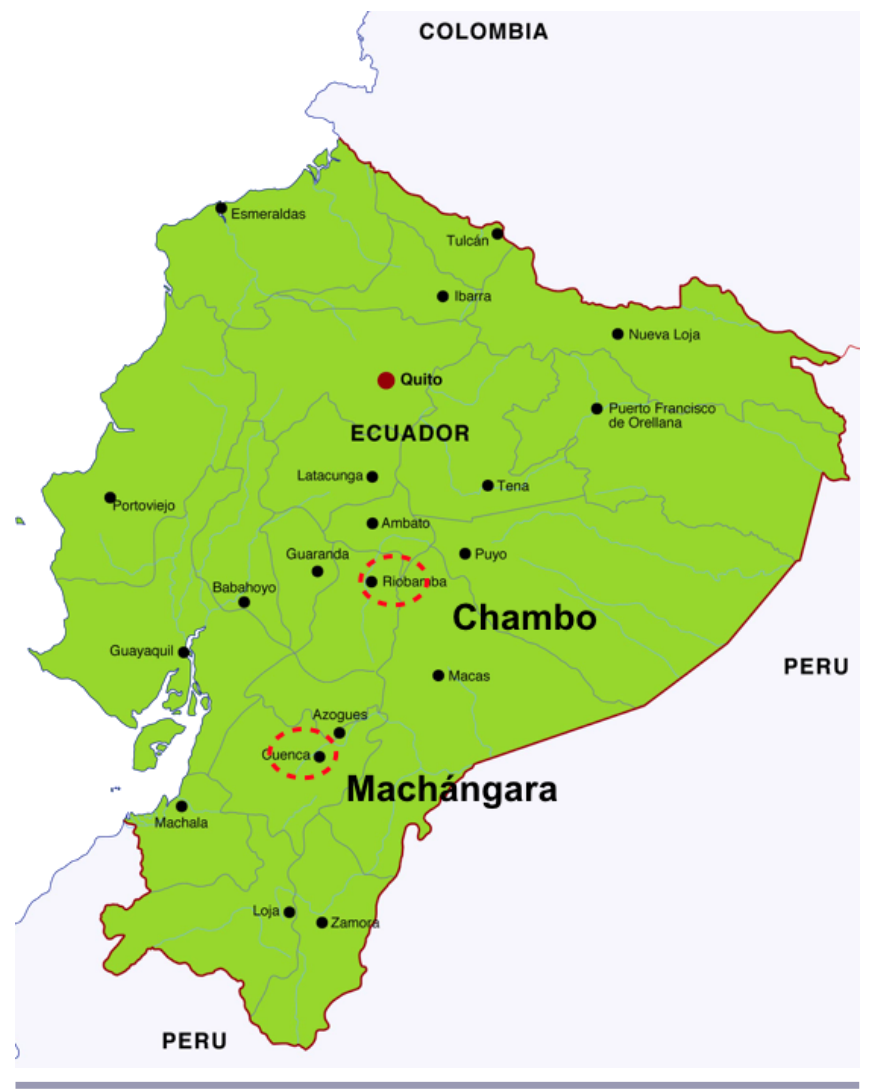

The partnerships of interest differ in one crucial aspect: whereas the Machángara River Council implemented controlled changes to its structure and function to respond to the regulatory changes, all the organizations in Chambo Rover Committee defected during the first year of implementation, and the partnership ceased to exist. This difference in outcome is the basis to compare the cases. It allows us to employ a counterfactual logic to eliminate variables from the explanation of the outcome of interest if they are present in the positive and the negative case (see Beach and Pedersen 2016). The application of the same theoretically informed questions to both cases, and the collection of data through a standardized questionnaire facilitates the comparative analysis. The within-case part of the analysis relies on investigating the congruence of the empirical observations from each case with the theorized relationships among the variables presented in the conceptual framework (see George and Bennett 2005).

The comparison of the cases focuses on the production of resilience as a critical outcome of collaborative governance. It does not investigate how policy reforms and the changes in the partnerships affected management outcomes such as water quality or biodiversity conservation. However, the study does not assume that partnerships produced effective management outcomes before or after the reforms. Following Sabatier and others $(2005 b)$, the variable of perceived effectiveness is used as the best proxy to understand how management outcomes play in the production of resilience. As I will show below, a majority of actors from both partnerships reported a positive perception of the partnership's effectiveness. Therefore, I assumed that enough incentives for working toward maintaining the partnerships existed and that dissatisfaction with management outcomes was not the main cause for defection in one of the partnerships.

\section{Data collection and analysis}

A standardized questionnaire was used to gather data for both cases. It was applied the year before the implementation of the new regulations (2015) and on each of the first two years of implementation (2016 and 2017). Table 1 presents the operationalization of the variables contained in the questionnaire.

I used a standardized survey questionnaire to collect information from representatives of the organizations identified as members of each partnership and people nominated by them. Respondents include elected representatives of local water boards, public servants, employees of public utilities and third sector organizations, and university professors. In total, 22 respondents answered the questionnaire. Additionally, I conducted 30 indepth interviews with partnership representatives and other key informants between 2015 and 2018 (see the complete list of respondents in Table A1.1). All respondents received information about the objective of the study, and they were asked for their consent to include their names in a roster. Additionally, respondents were informed that all information collected will be treated confidentially and that opting out of the study was possible at any time.

Appendix 2 shows the five sections of the questionnaire. The first section collected information on the attributes of the organizations. The second section gathered structural data on the networks using a roster. The roster was built in two steps using the reputational approach. I started with a list of partnership members compiled from official documents. Each year, network coordinators validated these lists during in-depth interviews. Then, respondents were presented with the roster and asked to identify other organizations to which they interacted as part of the partnership in the past year. I contacted representatives from all the organizations identified and repeated this process until I reached saturation. The third section of the questionnaire included a battery of questions about perceived legitimacy and the fourth section examined the perceptions of effectiveness. The last section collected information on other decision-making venues related to water governance in which the respondent's organization participated during the previous year and contact information on other actors involved in water governance in the watershed.

\section{A changing policy context}

Ecuador has a long history of unequal distribution of access to vital resources such as land and water. Policies have privileged large-scale farming operations that produce for external markets over small-scale farmers (Gaybor 2008). The country has also struggled to provide secure drinking water and sanitation for a considerable portion of its population, especially in the rural areas (Isch 2009). Policies to reduce these inequalities were first put in place during the nationalist governments of the 1970s when the country invested in the development of infrastructure to improve the access of small farmers to irrigation and of drinking water in 
Table 1. Variable operationalization and measurement.

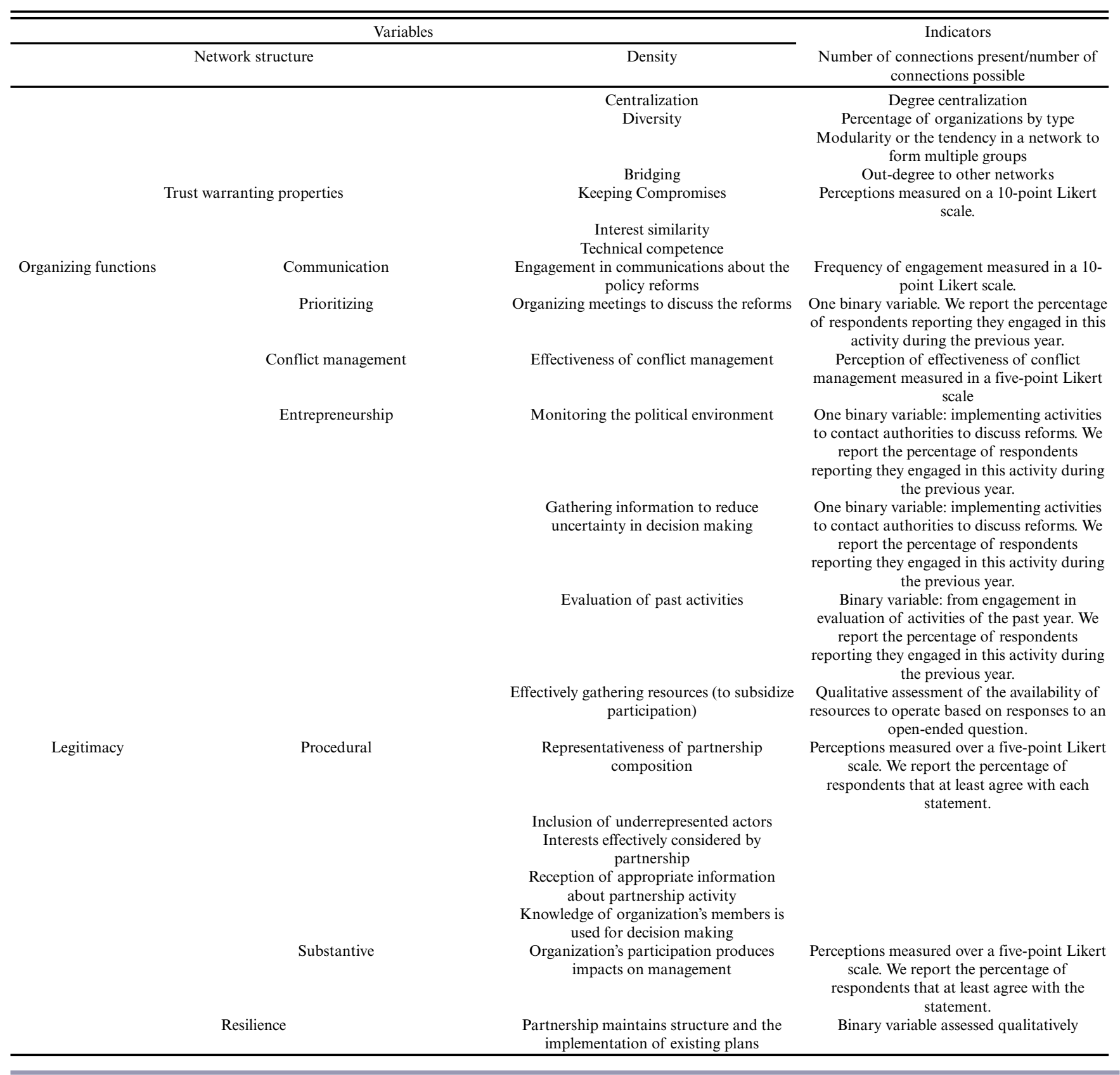

rural areas. The state operated these infrastructures directly until the 1990s when the government transferred their operation to water boards formed by local organized users. However, in many cases, these organizations were not granted the corresponding permits stressing the relationships between boards and local water agencies (Recált 2011). The concentration of water rights increased during the 1990s with the creation of regional development corporations. These organizations were controlled by powerful economic groups, which further increased their access to water through public infrastructures (Terán 2007).

The emergence of the indigenous and peasant's movement in the early 1990 s prevented the advance of privatizations, but effective redistribution of water remained as one of the most salient policy issues until 2006 when Rafael Correa was elected president (Moreano et al. 2016). During his first government, Correa announced an institutional reform to reverse decades of fragmented governance and lack of planning with a national perspective, and to steer water policy toward improved public management to guarantee the human right to water (Recált 2011). The National Secretariat for Water (SENAGUA is the acronym in Spanish) was created in 2008 to improve vertical coordination across the sector by defining policy and commanding the development of large-scale infrastructure projects. The promotion of stakeholder participation through watershed-based 
governance was another central objective of this reform (SENPLADES 2007). The new national constitution in late 2008 ratified this reform and mandated the elaboration of a sectoral law in 300 days. The legislative process sparked a political conflict between the government and social organizations about the content of the new water law. The government proposed a homogenous structure for all watershed councils, but civil society organizations demanded open arrangements, in part to maintain existing governance structures (E30).

Additionally, the government proposed that councils should have an advisory role while local organizations demanded councils to make binding decisions for all parties involved, including the national authority. The supportive majority that Correa had in the legislature made the government's proposal prevail, and enacted a new water law in August 2014 (Ley Orgánica de Recursos Hídricos, Uso y Aprovechamiento del Agua). In March 2015, the government issued the corresponding bylaws (Reglamento a la Ley Orgánica de Recursos Hídricos, Uso y Aprovechamiento del Agua), with implementation starting in late 2015. With this reform, Ecuador adopted regulations on stakeholder participation for water governance for the first time.

According to these regulations, stakeholder participation in river basin councils is open to organized water users (such as water boards and organized large-scale farmers), local governments in all three levels (provincial, municipal, and parish), and universities. These organizations participate in the council through representatives elected for a two-year period in a process coordinated by SENAGUA. The new regulations exclude NGOs and interested individuals despite the vital role these had in previous water governance initiatives in the past (Moscoso Sánchez 2006, Stanley 2006, Kauffman 2014). It is also important to note that the new legal framework does not include mechanisms to allow the conversion, or integration, of existing partnerships into the new councils, which means that existing partnerships would have to transform, disappear, or operate in a parallel system.

\section{Description of the cases}

The Machángara River council

The Machángara watershed is located in the province of Azuay, in southern Ecuador. It covers an area of $325 \mathrm{~km}^{2}$ and provides roughly $50 \%$ of the water used in the city of Cuenca $(580,000$ inhabitants). It also has domestic and industrial uses, approximately 2000 small farming operations $(<5 \mathrm{Ha})$, and its waters are used to generate electricity. In 1998, the regional water agency, the municipality of Cuenca, the public utilities (ELECTAUSTRO and ETAPA), and the University of Cuenca voluntarily formed the Machángara River Council to coordinate efforts to protect the natural resources of the watershed. Within a decade, the council expanded to include the Ministry of Agriculture, the Ministry of the Environment, the General Board of water users of Machángara (Machángara Board), and the provincial government of Azuay. These organizations got together to tackle deforestation provoked by the expansion of the agricultural frontier in the Machángara watershed although roughly $78 \%$ of the area was under the protection of the national protected areas system. To stop and revert this situation, the Council's members acquired land for conservation, established protected areas, implemented campaigns for environmental education and wildfire control, and financed the development of small business by local farmers to contain land use change. The council also assisted local farmers to incorporate nearly 4300 hectares to the SocioBosque program, a national povertyreduction program from which local landowners receive economic incentives for conservation. A crucial issue for the council has always been the expansion of ETAPA's water provision system to serve the city of Cuenca. Members of the Machángara Board have criticized the expansion of the system because rural areas remain deprived of quality services. The board has also demanded support from ETAPA to improve its crumbling infrastructure but the company demands that local boards improve their internal management and charge real prices for providing services, which is not always welcomed by the local communities (Cisneros 2017).

\section{The Chambo River committee}

The Chambo River Basin is located in central Ecuador, in the province of Chimborazo. This basin occupies an area of $3580 \mathrm{~km}^{2}$ and hosts agricultural, domestic, and industrial uses. The current allocation of water rights in Chambo produce a scarcity of water for irrigation and human consumption, with the vast majority of water allocated to landowners with large properties. Additionally, the low rate of access to sanitation in the city of Riobamba (220,000 inhabitants) contributes to the pollution of the water streams and the deterioration of health, especially among rural dwellers (Dávila and Olazával 2006). In the late 1990s, this situation motivated local water users to mobilize for the fair allocation of water rights. In 2000, they formed the Interjuntas Federation, which adopted the role of mediator among local water users and between them and the local water agency (Sosa 2008). Considering this state of affairs, the NGOs Central Ecuatoriana de Servicios Agrícolas (CESA) and Agronomes \& Vétérinaires Sans Frontières (AVSF) launched an initiative in 2007 to bring together stakeholders in the Chambo watershed to promote integrated water management. In 2008, this partnership created a special fund to protect the water resources for Riobamba allocating resources for environmental education and monitoring of the resources of the watershed. With the involvement of other actors such as local universities and local ministry agencies, the partnership implemented a diagnostic of the watershed, carried out an inventory of water-rights, and in 2010, initiated the definition of a management plan with support from SENPLADES (Secretaría Nacional de Planificación y Desarrollo, or the National Secretariat for Planning and Development). By 2013 the partnership had created four specialized commissions to implement activities contained in the management plan. When implementation of the new regulations began, SENAGUA refused to maintain the existing management plan, and by the end of 2016 announced a process to form a new watershed council in Chambo. This decision motivated the defection of all organizations in early 2016, and no parallel structures emerged to maintain existing activities.

\section{RESULTS AND DISCUSSION}

\section{Density, trust, and communication}

Table 2 shows that before the implementation of the new regulations, the Machángara partnership had a higher network density than Chambo. This difference suggests that more organizations interacted with each other in Machángara to make decisions and implement everyday activities. However, these 
Fig. 3. Networks in 2015.

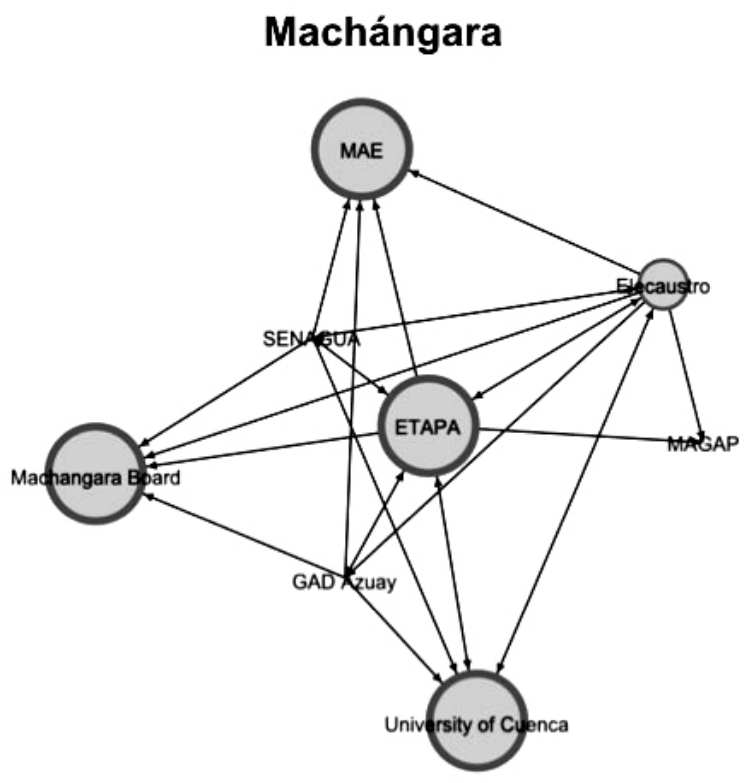

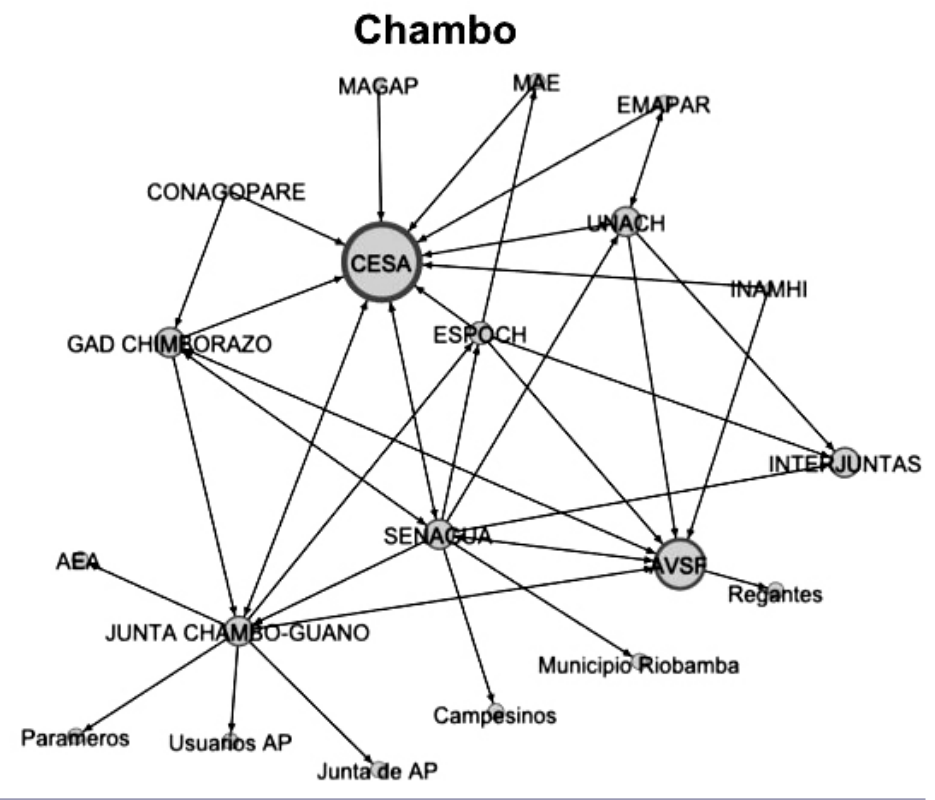

Table 2. Network density and centralization in 2015.

\begin{tabular}{lccc}
\hline \hline Network & Nodes & Density & Centralization \\
\hline Machángara & 8 & 0.446 & 0.904 \\
Chambo & 20 & 0.111 & 0.515 \\
\hline
\end{tabular}

measures are not directly comparable given that density is affected by network size. Because larger networks have a greater potential for more ties, only comparisons of networks of the same size are informative of how well connected the networks are (Prell 2012). In this case, Chambo doubled Machángara in the number of nodes; however, qualitative data about the interactions within each network allows a comparison. In 2015, civil society organizations working in collaborative water management convened several events to discuss the regulatory changes and to share lessons from past experiences. Representatives from both partnerships participated in these events. During a discussion about the diversity of experiences in collaborative water management in the past decade, a respondent described the Machángara River council as an example of a "tightly connected group of actors that interact with each other at some point in time." The same person described Chambo as "groups of actors loosely connected by two NGOs" (E30). The sociograms depicted in Figure 3 fit this qualitative description. The networks in Figure 3 were elicited using the number of connections among partnership members detected with the questionnaire. Each node represents an organization, and the size of each node corresponds to the number of mentions an organization received from others as a partner. The sociograms show that most nodes are interconnected to a variety of other nodes in Machángara. In Chambo, a considerable number of nodes are connected by only one or two nodes. From this finding, I conclude that Machángara was effectively denser than Chambo before implementation of the new regulations began.
The two partnerships also differ with regard to the distribution of trust among their members. The histograms and the shape of the distribution presented in the left column of Figure 4 show that trust distributed more evenly in Machángara. The distribution of trust shown in the boxplots in the right column of Figure 4 indicates higher trust in Machángara because there is more concentration around a higher median value as well as less dispersion of the data. As I highlighted in the theoretical section, density and trust influence communication within the network. The expectation was to find evidence of more internal discussions

Fig. 4. Distribution of trust in 2015.

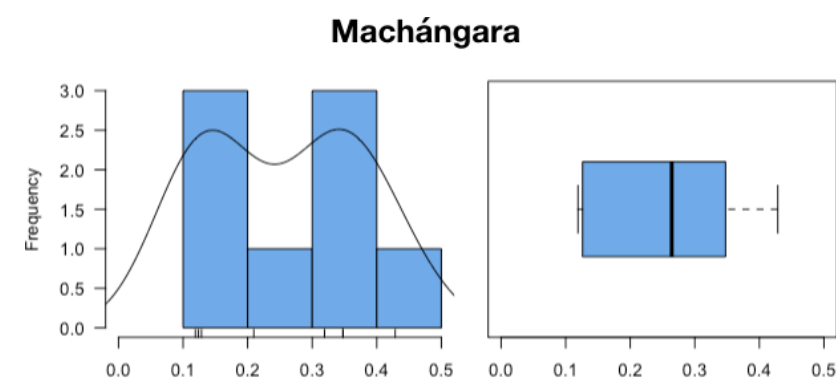

Chambo
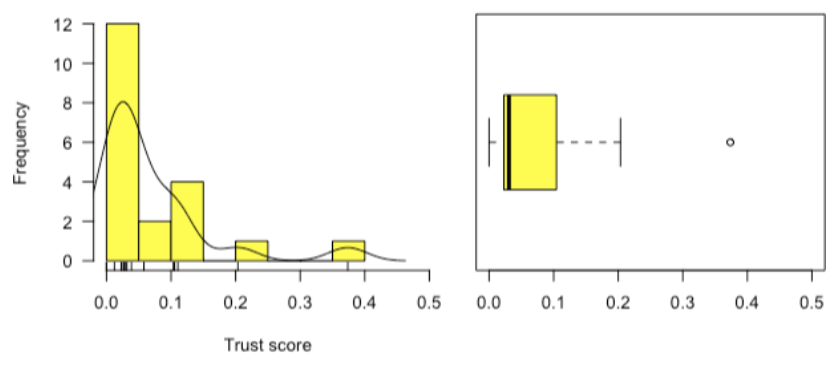
about policy change in the network with higher density and higher levels of trust. The second row in Table 3 shows that a slightly higher percentage of actors in Chambo reported engaging in these activities. Therefore, I reject H1. Respondents from Chambo explain this unexpected level of activity on account of the considerable uncertainty created in the partnership by the discussions of the new regulations. The members of this network were not able to predict if the new regulations would affect the structure and availability of resources of the partnership. A major concern was whether SENAGUA would maintain the management plan they elaborated for the watershed; therefore, they organized meetings seeking for SENAGUA to clarify its position (E10, E13).

Table 3. Performance of the organizing functions in 2015.

\begin{tabular}{|c|c|c|c|}
\hline \multicolumn{2}{|c|}{ Organizing functions } & \multirow{2}{*}{$\frac{\text { Machángara }}{50 \%}$} & \multirow{2}{*}{$\frac{\text { Chambo }}{58 \%}$} \\
\hline Communication & $\begin{array}{l}\text { Communication about } \\
\text { policy change }\end{array}$ & & \\
\hline Prioritizing & Analyzing reforms & $\begin{array}{c}60 \% \\
100 \%\end{array}$ & $\begin{array}{c}50 \% \\
100 \%\end{array}$ \\
\hline \multicolumn{4}{|c|}{ Conflict management $^{\dagger}$} \\
\hline \multirow[t]{4}{*}{$\begin{array}{l}\text { Entrepreneur- } \\
\text { ship }\end{array}$} & $\begin{array}{l}\text { Monitoring the political } \\
\text { environment }\end{array}$ & $40 \%$ & $42 \%$ \\
\hline & $\begin{array}{l}\text { Gathering information to } \\
\text { reduce uncertainty in } \\
\text { decision making }\end{array}$ & $60 \%$ & $50 \%$ \\
\hline & $\begin{array}{l}\text { Evaluation of past } \\
\text { activities }\end{array}$ & $20 \%$ & $50 \%$ \\
\hline & $\begin{array}{l}\text { Effectively mobilizing } \\
\text { additional resources }\end{array}$ & Yes & No \\
\hline
\end{tabular}

Unless otherwise noted, percentages show the proportion of respondents from organizations that engaged in the activity during the previous year.

'Shows the proportion of respondents who agree that their partnership is capable of solving conflicts between members.

\section{Centralization, prioritizing, and conflict management}

As shown in Table 2, network centralization was higher in Machángara because a small number of organizations concentrated a large number of the interactions among the partnership members. As presented above, the general level of trust was also higher in Machángara. According to H2, high levels of centralization and trust should manifest in improved capacity to prioritize activities. Table 3 shows that Machángara performed better than Chambo in prioritizing. This finding offers support for $\mathrm{H} 2$, and qualitative offers valuable insight into how the process unfolded. During interviews with representatives from Chambo the difficulties to identify how to proceed in the face of the reform were mentioned repeatedly (E1, E10, E12). The two NGOs that coordinated the network were reorienting their activities outside the watershed, in part because of the inability to predict future scenarios for collaboration. On the other hand, respondents from Machángara highlighted the leadership of ELECAUSTRO and ETAPA in narrowing down options to adapt to the new regulatory framework (E6, E2).

\section{Diversity, conflict management, and resource mobilization}

The two measures of diversity presented in Table 4 show that Chambo was more diverse than Machángara in 2015. Only five types of organizations existed in Machángara, whereas Chambo had 10. The modularity analysis shows that the Chambo network had a higher tendency to form cohesive groups than Machángara. In other words, fewer nodes have to be removed from the Chambo network to fracture it into smaller pieces than in Machángara.

Table 4. Network diversity in 2015.

\begin{tabular}{lcc}
\hline \hline & Types of actors & $\begin{array}{c}\text { Groups in modularity analysis (min- } \\
\max \text { ) }\end{array}$ \\
\hline Machángara & 5 & $1-2$ \\
Chambo & 10 & $4-5$ \\
\hline
\end{tabular}

On the other hand, Table 3 shows no difference regarding the perception of networks' capability to manage internal conflict. Contrary to the expectation presented in $\mathrm{H} 3$, the higher diversity in Chambo was not associated with a higher capability to mobilize resources to sustain collaboration. Qualitative data confirm that by the end of 2015, AVSF and CESA, the actors that traditionally mobilized resources for the Chambo partnership, were unsuccessful to secure additional resources from donors to continue working in Chambo (E10, E13, E20, E26, E28). As a result, partnership members did not agree on a working plan for 2016. On the other hand, by late 2015 organizations in the Machángara partnership were committed to continuing their collaboration and agreed on a working plan for the following year (E6).

\section{Bridging and entrepreneurship}

The networks under study present considerable differences with regard to bridging or how nodes connect to other water governance networks from which they draw resources. Respondents from Machángara reported a total of 23 connections during 2015. These networks include local and regional government programs and projects, as well as management initiatives launched by grassroots organizations, all located within the province of Azuay. On the other hand, respondents from Chambo reported 16 external connections. These include national venues where actors exchange information about water regulations such as the National Forum for Water Resources and other emergent initiatives for collaborative water governance outside the province of Chimborazo.

External connections in Machángara are also more redundant than connections in Chambo. Whereas organizations in Machángara shared $17 \%$ of the external connections, organizations in Chambo only shared $6 \%$ of these connections. Qualitative data show that the context where each partnership operates matters to explain how organizations seek connections elsewhere. During interviews, respondents in Machángara indicated their organizations have access to resources within the province of Azuay; thus, they do not seek support from the national government to sustain collaboration (E8, E6). Meanwhile, respondents from Chambo indicated that resources provided by local actors, such as provincial and city governments and the water utility, were not enough to sustain collaboration; therefore, they sought additional resources in national and international venues (E20, E28).

Machángara performed better in some entrepreneurial actions. Table 3 shows the proportion of respondents who reported their 
Table 5. Perceived legitimacy in 2015.

\begin{tabular}{llcc}
\hline \hline Legitimacy & & Machángara (Agree) & Chambo (Agree) \\
\hline Procedural & The composition of the partnership reflects the existing interests in & $100 \%$ & $83 \%$ \\
& stakeholders in the watershed & $100 \%$ & $83 \%$ \\
& Partnership coordinators motivate underrepresented actors to participate & $100 \%$ & $100 \%$ \\
& The interests of your organization are considered in the partnership & $100 \%$ & $100 \%$ \\
& Your organization receives appropriate information about the partnership & $67 \%$ & $100 \%$ \\
The knowledge that members of your organization have is used for & $75 \%$ \\
Substantive & decision making in the partnership & & \\
& The participation of your organization produces impact on the & & \\
& management of the watershed &
\end{tabular}

organization engaged in each of the four entrepreneurial actions of interest. First, there were no differences in how partnerships monitored the political environment and how they gathered information to reduce uncertainty in decision making. Second, Machángara outperformed Chambo with regard to the mobilization of new resources. This partnership drew resources from SENAGUA and a European university to sustain activities with their local partners. Additionally, actors in Machángara worked with the national environmental authority in two activities: a project proposal for the Global Environmental Fund (GEF) to fund future activities, and the expansion of area included in the SocioBosque program that provides incentives to local farmers to maintain their operations outside of watercatchment areas (E6). Machángara received funds from GEF in 2018.

Finally, the number of actors that engaged in evaluations of past activities was more salient in Chambo. The reason is that AVSF and CESA were required to register with the Technical Secretariat for International Cooperation and to align their activities to the National Development Plan. On the other hand, interviewees indicated the Machángara council met once to evaluate past activities to build a work plan for 2016 (E6).

These findings provide partial support for $\mathrm{H} 4$ because the network with more and more redundant external connections improved the performance of just two out of four entrepreneurial actions. These findings suggest that expanding the universe of relationships to draw additional resources may be the most crucial entrepreneurial action in times of change.

\section{Organizing functions, legitimacy, and resilience}

Table 5 shows the characteristics of perceived legitimacy in each network. The percentages correspond to the proportion of respondents that agreed with the statement presented in the first column of Table 5. Machángara scored higher than Chambo in all but one criteria of procedural legitimacy. It is of particular importance to notice that although Machángara was a more centralized network, it received a better evaluation than Chambo for its capacity to be inclusive of watershed stakeholders and their specific forms of knowledge. There was no difference concerning the appropriateness of the information received by partnership members from their coordinators. One of the most important differences between networks relates to substantive legitimacy. The comparison favored Machángara because more respondents agreed that their participation in the partnership produced a positive effect on the watershed. This suggests that dissatisfaction with the outcomes of collaboration could have played a role in facilitating defection from the Chambo partnership. However, this variable does not fully explain defection because the issue was not raised during interviews before the reforms. On the other hand, most respondents expressed confidence that the partnership was indeed working toward implementing effective actions.

As presented in $\mathrm{H} 5$, I expected better performance and higher levels of perceived legitimacy to associate positively with resilience. Whereas organizations in Machángara continued their collaborative activities through 2016 and 2017, all the organizations in Chambo defected from the partnership in 2016. These findings provide support for $\mathrm{H} 5$, and qualitative data explain this outcome showing the contrast between the case where no resilience was found with the positive case.

In late 2015, SENAGUA refused to adopt the management plan for the Chambo watershed developed by the partnership in previous years. Additionally, the most central actors of the network, AVSF and CESA, moved on to new projects in other regions. CESA raised funds to start a new project to replicate the partnership model in the Cutuchi watershed located in the Cotopaxi province. The remaining organizations defected when SENAGUA announced the formation of a new council in Chambo structured according to the new regulations. These organizations did not regroup to resume collaborative work in the watershed (E20, E26, E28) and they had not met until mid-2018 when data collection for this project came to an end. Interjuntas federation was the only nonstate actor that participated in the process headed by SENAGUA to elect a representative to the new council in mid-2016. This process revived internal conflicts in Interjuntas because members quarreled about continuing work with SENAGUA. The new Chambo council was inactive during 2017 and 2018 (E31).

On the other hand, when the implementation of the new regulations began in late 2015, members of the Machángara partnership continued collaboration toward the expansion of water provision and sanitation infrastructures and the consolidation of protected areas. A central activity to achieve these goals was strengthening the relationship with the local governments at the parish level (Juntas Parroquiales or JPs). JPs in Ecuador have authority over water quality, planning, and land use management but lack resources to implement local development plans. They are also essential for decision making within their jurisdiction. Council members expected that JPs 
Table 6. Characteristics of the Machángara network in 2016 and 2017.

\begin{tabular}{|c|c|c|c|c|}
\hline Variables & & 2015 & 2016 & 2017 \\
\hline \multirow[t]{4}{*}{ Network characteristics } & Density & 0.446 & 0.321 & 0.482 \\
\hline & Centralization & $13 \%$ & $31 \%$ & $43 \%$ \\
\hline & Diversity & \multicolumn{3}{|c|}{ Same composition and number of subgroups } \\
\hline & Bridging & Regional & Local & Local \\
\hline Trust & & 0.25 & 0.191 & 0.427 \\
\hline Conflict management & & $100 \%$ & $70 \%$ & $100 \%$ \\
\hline \multirow[t]{2}{*}{ Entrepreneurship } & $\begin{array}{l}\text { Effectively gathering } \\
\text { additional resources }\end{array}$ & Yes & Yes & Yes \\
\hline & $\begin{array}{l}\text { Effectively connecting the } \\
\text { initiative with new venues }\end{array}$ & Yes & Yes & Yes \\
\hline \multirow[t]{2}{*}{ Legitimacy } & Procedural & $100 \%$ & $82 \%$ & $89 \%$ \\
\hline & Substantive & $100 \%$ & $86 \%$ & $100 \%$ \\
\hline
\end{tabular}

could help reinforce the commitment of the local farmers to keep their crops off the limits of protected areas.

The changing dynamics of the partnership during the implementation of the activities mentioned above influenced changes in the performance of the network. Table 6 shows that indicators of the characteristics of the network structure fell between 2015 and 2016 but increased again in 2017. In the case of density, this change suggests that despite the implementation of the new regulations, the network was able to maintain the interactions among members. Centralization more than doubled in 2016 and rose again in 2017, which suggests that formerly powerful actors improved their capacity to influence the network. This assessment is valid for the utility ELECAUSTRO whose representatives are regarded by respondents as the "political muscle" of the partnership (E2, E6, E9). It was under the leadership of ELECAUSTRO's manager, who has been part of the partnership and presided over it for more than 10 years, that negotiations with SENAGUA to continue collaborative actions were possible. Qualitative data also indicate that the relative reduction of the activity of two organizations in 2016 explains the changes in density and centralization. SENAGUA appointed a new representative to the council, who was less engaged in partnership activities than its predecessor (E6, E9, E8). This change reflects SENAGUAS's institutional instability because of changes in the national directives and lack of resources to operate (E31). Additionally, the representative from the provincial government was absent from most partnership meetings in 2016 because of a political conflict between the provincial government of Azuay and the municipal government of Cuenca that was not specific to the partnership (E16, E27).

Between 2015 and 2017 the diversity of the partnership remained constant because JPs were not formally incorporated. Members of the partnership agreed that although JPs are essential stakeholders in the watershed, their limited technical capacity does not warrant their formal inclusion in the Council (E6, E9). On the other hand, there were notable changes in the characteristics of bridging because the number of external connections to other networks operating in the watershed increased. The emphasis put in negotiations with JPs and local water boards for the expansion of ETAPAS's infrastructure explain this change. The conflicts that emerged during these negotiations between ETAPA and JPs explain the low levels of trust, perceived conflict management effectiveness, and the perception of procedural legitimacy reported in 2016.

SENAGUA was a critical actor in the production of agreements between JPs and ETAPA to advance with the infrastructures. Although not all of the local water boards supported ETAPA's plans, the agreements achieved were enough to allow the projects to move forward. Therefore, once the implementation of the infrastructure projects began in 2017, the levels of trust, effective conflict management, and perceived legitimacy in the Machángara network increased.

Conflicts between ETAPA and the local water boards and JPs also helped the Council to steer SENAGUA to support the partnership. Continued pressure from ETAPA, ELECAUSTRO, and the Machángara Board to continue their collaborative actions culminated with an agreement in which SENAGUA accepted the participation of these organization's representatives in the Santiago watershed council, which is the larger hydrological unit to the Machángara basin.

Despite the effective interactions with SENAGUA, members of the Machángara Council decided to reframe their actions outside the realm of water governance. They changed the Watershed Council to a Committee for the Conservation of the Machángara Watershed, which puts their collaboration efforts under the realm of the Ministry of Environment, a weaker member of the partnership. With this decision, organizations limit the control that SENAGUA can exert over its activities. With this decision, the partnership members in Machángara were able to maintain their primary composition and functions, altering the identity of the initiative only enough to allow for its continuity.

\section{CONCLUSIONS}

In this paper, I show how the new regulations for stakeholder participation in water governance passed in Ecuador between 2014 and 2015 had adverse effects on existing water governance partnerships. The reforms impacted the social ties in these networks, encouraging actors to defect or to collaborate in the margins of the regulatory space of water governance.

The characteristics of network structures were used to explain differences in the resilience capacity of partnerships to withstand regulatory changes. The denser and more centralized network was more resilient than the more diverse network because it was able 
to foster trust among its participants, perform essential functions more effectively, and produce legitimacy of its actions and outcomes. The internal diversity of this network was less critical to generating resilience than anticipated in the existing literature on natural resource governance. Moreover, our data show that the type of diversity matters for mobilizing resources effectively. When diversity is linked to high dependence on external actors to fund the basic activities of the network, a changing policy context can affect the continuity of the flow of resources reducing resilience. On the other hand, the availability of local resources to subsidize participation, the number and redundancy of connections to other networks, and the capacity to establish new external connections, improved the capacity of the resilient partnership to control the direction of change. This finding is in line with previous work that shows the importance of supportive environments in the United States to generate adaptive capacity and resilience because they provide enough resources to define and implement new strategies (Koontz et al. 2015).

The cases analyzed in this paper show that changes in the regulations that homogenize stakeholder participation in water governance units could deepen structural inequalities by making it harder for some actors to collaborate. This finding is relevant for the implementation of Goal 6 of the SDGs in developing countries where policy regimes are unstable, and the stakeholders of water governance often depend on the presence of external actors that subsidize participation and the implementation of agreements. Moreover, considering that backlashes against NGOs and foreign aid agencies are increasing in developing countries (Ron et al. 2012, Dupuy et al. 2016), international donors should be wary of the potential contribution they can make to establishing or strengthening collaborative structures for water governance, especially in contexts where participation is limited by homogenizing regulations. Success in accomplishing these tasks will likely depend on how capable governments and sectoral authorities are to define mechanisms that secure the participation of local or nonlocal stakeholders that can subsidize participation directly. It is also important to note that although developing or updating legal frameworks to implement the participatory watershed approach, authorities should make sure that initiatives to reinforce the power and capacities of public agencies do not reduce the ability of pre-existing governance structures to operate.

Finally, a complete examination of the interactions among the components of the conceptual framework presented in this paper requires analyses of more extensive sets of data on collaborative governance to adequately assess the role of other external perturbations over the production of resilience, such as socioeconomic changes or the effects of decisions from other subsystems. Moreover, future applications of the conceptual framework should strive to include more refined mechanisms to assess the effects of these dynamic factors on resource quality, availability, and distribution.

Responses to this article can be read online at: http://www.ecologyandsociety.org/issues/responses. php/10667

\section{Acknowledgments:}

An earlier version of this paper was presented at the 2017 Water, Inclusion and Visions of Development workshop in Stockholm, Sweden, and the article benefited from discussants' feedback. I thank María Mancilla Garcia and Matthew Hamilton for helpful comments on earlier drafts of the paper. I additionally thank Mark Lubell who provided a stimulating academic environment for the development of this research at the Center for Environmental Policy and Behavior (CEPB) in the University of California, Davis. This research was supported by Secretaría de Educación Superior, Ciencia y Tecnología e Innovación (SENESCYT) under grant 27107.

\section{LITERATURE CITED}

Abers, R. N. 2007. Organizing for governance: building collaboration in Brazilian river basins. World Development 35 (8):1450-1463. http://dx.doi.org/10.1016/j.worlddev.2007.04.008

Armitage, D., and R. Plummer, editors. 2010. Adaptive capacity and environmental governance. Springer, Berlin, Germany. http:// dx.doi.org/10.1007/978-3-642-12194-4

Arrow, K. J., P. R. Ehrlich, and S. A. Levin. 2014. Some perspectives on linked ecosystems and socio-economic systems. Pages 95-116 in S. Barrett, K.-G. Maler, and E. S. Maskin, editors. Environment and development economics: essays in honour of Sir Partha Dasgupta. Oxford University Press, Oxford, UK.

Barrera, V. H., J. Alwang, and E. Cruz, editors. 2010. Experiencias de manejo integrado de recursos naturales en la subcuenca del río Chimbo, Ecuador. Editorial ABYA-YALA, Quito, Ecuador.

Beach, D., and R. B. Pedersen. 2016. Causal case study methods: foundations and guidelines for comparing, matching, and tracing. University of Michigan Press, Ann Arbor, Michigan, USA. http:// dx.doi.org/10.3998/mpub.6576809

Bodin, Ö., B. Crona, and H. Ernstson. 2006. Social networks in natural resource management: What is there to learn from a structural perspective? Ecology and Society 11(2):r2. http://dx. doi.org/10.5751/ES-01808-1102r02

Bodin, Ö., and S. Ramirez-Sanchez, H. Ernstson, and C. Prell. 2011. A social relational approach to natural resource governance. Pages 3-28 in Ö. Bodin and C. Prell, editors. Social networks and natural resource management. Cambridge University Press, Cambridge, UK. http://dx.doi.org/10.1017/CBO9780511894985.002

Boin, A., and M. Lodge. 2016. Designing resilient institutions for transboundary crisis management: a time for public administration. Public Administration 94(2):289-298. http://dx. doi.org/10.1111/padm.12264

Boyd, E., and C. Folke, editors. 2012. Adapting institutions: governance, complexity and social-ecological resilience. Cambridge University Press, Cambridge, UK. http://dx.doi.org/10.1017/ CBO9781139017237

Brown, K. 2015. Resilience, development and global change. Routledge, London, UK. http://dx.doi.org/10.4324/9780203498095 
Butts, C. T. 2008. Social network analysis: a methodological introduction. Asian Journal of Social Psychology 11(1):13-41. http://dx.doi.org/10.1111/j.1467-839X.2007.00241.x

Carlsson, L. G., and A. C. Sandström. 2008. Network governance of the commons. International Journal of the Commons 2 (1):33-54. http://dx.doi.org/10.18352/ijc. 20

Castro, J. E. 2007. Water governance in the twentieth-first century. Ambiente \& Sociedade 10(2):97-118. http://dx.doi.org/10.1590/ S1414-753X2007000200007

Cisneros, P. 2017. ¿Por qué no avanza la megaminería en el Ecuador? Pages 57-84 in L. Bottaro and M. Sola Álvarez, editors. Agua y megaproyectos mineros en América Latina. Universidad Nacional de General Sarminento, Buenos Aires, Argentina.

Dávila, G., and H. Olazával. 2006. De la Mediación a La Movilización Social. Editorial ABYA-YALA, Quito, Ecuador.

Dupuy, K., J. Ron, and A. Prakash. 2016. Hands off my regime! Governments' restrictions on foreign aid to non-governmental organizations in poor and middle-income countries. World Development 84:299-311. http://dx.doi.org/10.1016/j.worlddev.2016.02.001

Eakin, H., and M. C. Lemos. 2006. Adaptation and the state: Latin America and the challenge of capacity-building under globalization. Global Environmental Change 16(1):7-18. http://dx. doi.org/10.1016/j.gloenvcha.2005.10.004

Embid, A., and L. Martín. 2015. La experiencia legislativa del decenio 2005-2015 en materia de aguas en América Latina. CEPAL, Santiago de Chile, Chile.

Engle, N. L., O. R. Johns, M. C. Lemos, and D. R. Nelson. 2011. Integrated and adaptive management of water resources: tensions, legacies, and the next best thing. Ecology and Society 16 (1):19. http://dx.doi.org/10.5751/ES-03934-160119

Falleti, T. G. 2010. Decentralization and subnational politics in Latin America. Cambridge University Press, Cambridge, UK. http://dx.doi.org/10.1017/CBO9780511777813

Fliervoet, J. M., G. W. Geerling, E. Mostert, and A. J. M. Smits. 2016. Analyzing collaborative governance through social network analysis: a case study of river management along the Waal River in The Netherlands. Environmental Management 57(2):355-367. http://dx.doi.org/10.1007/s00267-015-0606-x

Folke, C., T. Hahn, P. Olsson, and K. Norberg. 2005. Adaptive governance of social-ecological systems. Annual Review of Environment and Resources 30:441-473. http://dx.doi.org/10.1146/ annurev.energy.30.050504.144511

Gaybor, A. 2008. El despojo del agua y la necesidad de una transformación urgente. Foro de los Recursos Hídricos. Quito, Ecuador.

George, A. L., and A. Bennett. 2005. Case studies and theory development in the social sciences. MIT Press, Cambridge, Massachusetts, USA.

Grigg, N. S. 2016. Integrated water resource management. An interdisciplinary approach. Palgrave Macmillan, London, UK. http://dx.doi.org/10.1057/978-1-137-57615-6

Grindle, M. S. 2000. Audacious reforms. Johns Hopkins University Press, Baltimore, Maryland, USA.
Grugel, J., and P. Riggirozzi. 2009. Governance after neoliberalism in Latin America. Palgrave MacMillan, New York, New York, United States. http://dx.doi.org/10.1057/9780230622425

Heinmiller, B. T., and K. Pirak. 2017. Advocacy coalitions in Ontario land use policy development. Review of Policy Research 34(2):168-185. http://dx.doi.org/10.1111/ropr.12210

Henry, A. D., and B. Vollan. 2014. Networks and the challenge of sustainable development. Annual Review of Environment and Resources 39:583-610. http://dx.doi.org/10.1146/annurevenviron-101813-013246

Howlett, M., and M. Ramesh. 1998. Policy subsystem configurations and policy change: operationalizing the postpositivist analysis of the politics of the policy process. Policy Studies Journal 26(3):466-481. http://dx.doi.org/10.1111/j.1541-0072.1998. $\underline{\text { tb01913.x }}$

Isch, E. 2009. La gestión de los recursos hídricos en el Ecuador. REGA 6(2):33-48.

Janssen, M. A., Ö Bodin, J. M. Anderies, T. Elmqvist, H. Ernstson, R. R. J. McAllister, P. Olsson, and P. Ryan. 2006. Toward a network perspective on the resilience of socialecological systems. Ecology and Society 11(1):15. https://doi. org/10.5751/ES-01462-110115

Kauffman, C. M. 2014. Financing watershed conservation: lessons from Ecuador's evolving water trust funds. Agricultural Water Management 145:39-49. http://dx.doi.org/10.1016/j. agwat.2013.09.013

Koontz, T. M., D. Gupta, P. Mudliar, and P. Ranjan. 2015. Adaptive institutions in social-ecological systems governance: a synthesis framework. Environmental Science \& Policy 53:139-151. http://dx.doi.org/10.1016/j.envsci.2015.01.003

Lansberg-Rodríguez, D. 2016. Life after populism? Reforms in the wake of the receding pink tide. Georgetown Journal of International Affairs 17(2):56-65. http://dx.doi.org/10.1353/ gia.2016.0025

Lubell, M. 2007. Familiarity breeds trust: collective action in a policy domain. Journal of Politics 69(1):237-250. http://dx.doi. org/10.1111/j.1468-2508.2007.00507.x

Lubell, M., P. Sabatier, Z. Trachtenberg, A. Vedlitz, W. Focht, and M. Matlock. 2005. Conclusions and Recommendations. Pages 261-296 in P. A. Sabatier, W. Focht, M. Lubell, Z. Trachtenberg, A. Vedlitz, and M. Matlock, editors. Swimming upstream. MIT Press, Cambridge, Massachusetts, USA.

Mintrom, M., and P. Norman. 2009. Policy entrepreneurship and policy change. Policy Studies Journal 37(4):649-667. https://doi. org/10.1111/j.1541-0072.2009.00329.x

Moreano, M., K. Hopfgartner, and A. Santillana. 2016. La política económica de la reforma a la gobernanza del agua y las implicaciones para la desigualdad territorial El caso de Ecuador. RIMISP, Santiago de Chile, Chile.

Moscoso Sánchez, D. J. 2006. El proyecto de desarrollo rural EXPIDER. Las dificultades en la cuenca del Chanchán (Ecuador). Revista de Fomento Social 61(244):587-602.

Mosello, B. 2015. How to deal with climate change? Springer International, London, UK. http://dx.doi.org/10.1007/978-3-319-15389-6 
Nohrstedt, D. 2011. Shifting resources and venues producing policy change in contested subsystems: a case study of Swedish signals intelligence policy. Policy Studies Journal 39(3):461-484. http://dx.doi.org/10.1111/j.1541-0072.2011.00417.x

Pahl-Wostl, C., M. Craps, A. Dewulf, E. Mostert, D. Tabara, and T. Taillieu. 2007. Social learning and water resources management. Ecology and Society 12(2):5. http://dx.doi. org/10.5751/ES-02037-120205

Pahl-Wostl, C., P. Kabat, and J. Möltgen. 2008. Adaptive and integrated water management: coping with complexity and uncertainty. Springer International, Berlin, Germany. http://dx. doi.org/10.1007/978-3-540-75941-6

Pahl-Wostl, C., L. Lebel, C. Knieper, and E. Nikitina. 2012. From applying panaceas to mastering complexity: toward adaptive water governance in river basins. Environmental Science \& Policy 23:24-34. http://dx.doi.org/10.1016/j.envsci.2012.07.014

Peruzzotti, E. 2017. Regime betterment or regime change? A critical review of recent debates on liberal democracy and populism in Latin America. Constellations 24(3):389-400. http:// dx.doi.org/10.1111/1467-8675.12313

Poats, S. V. 2017. Gobernanza del Agua en la Cuenca del Río El Ángel. Carchi, Lima, Perú.

Prell, C. 2012. Social network analysis: history, theory and methodology. SAGE, Thousand Oaks, California, USA.

Recált, C. 2011. Entre la división y exclusión, políticas del agua en el Ecuador: el ejemplo andino de Píllaro. SIPAE, Quito, Ecuador.

Ron, J., A. Prakash, and K. E. Dupuy. 2012. Reclaiming political terrain: the regulatory crackdown on overseas funding for NGOs. Documentos de Trabajo del CIDE 232.

Sabatier, P. A. 1988. An advocacy coalition framework of policy change and the role of policy-oriented learning therein. Policy Sciences 21(2-3):129-168. http://dx.doi.org/10.1007/BF00136406

Sabatier, P. A., W. Focht, M. Lubell, Z. Trachtenberg, A. Vedlitz, and M. Matlock. 2005b. Collaborative approaches to watershed management. Pages 3-21 in P. A. Sabatier, W. Focht, M. Lubell, Z. Trachtenberg, A. Vedlitz, and M. Matlock, editors. Swimming upstream. MIT Press, Cambridge, Massachusetts, USA. http:// dx.doi.org/10.7551/mitpress/6577.003.0005

Sabatier, P., and D. Mazmanian. 1980. The implementation of public policy: a framework of analysis. Policy Studies Journal 8 (4):538-560. http://dx.doi.org/10.1111/j.1541-0072.1980.tb01266. $\underline{\mathrm{x}}$

Sabatier, P. A., P. Sabatier, W. D. Leach, M. Lubell, and N. W. Pelkey. 2005c. Theoretical frameworks explaining partnership success. Pages 173-199 in P. A. Sabatier, W. Focht, M. Lubell, Z. Trachtenberg, A. Vedlitz, and M. Matlock, editors. Swimming upstream. MIT Press, Cambridge, Massachusetts, USA. http:// dx.doi.org/10.7551/mitpress/6577.003.0012

Sabatier, P. A., C. Weible, and J. Ficker. 2005a. Eras of water management in the United States: implications for collaborative watershed approaches. Pages 24-52 in P. A. Sabatier, W. Focht, M. Lubell, Z. Trachtenberg, A. Vedlitz, and M. Matlock, editors. Swimming upstream. MIT Press, Cambridge, Massachusetts, USA. https://doi.org/10.7551/mitpress/6577.003.0006
Sandström, A. 2008. Policy networks: the relation between structure and performance. Dissertation. Luleå University of Technology, Luleå, Sweden.

Sandström, A., and L. Carlsson. 2008. The performance of policy networks: the relation between network structure and network performance. Policy Studies Journal 36(4):497-524. http://dx.doi. org/10.1111/j.1541-0072.2008.00281.x

Sandström, A., and C. Rova. 2010. Adaptive co-management networks: a comparative analysis of two fishery conservation areas in Sweden. Ecology and Society 15(3):14. http://dx.doi. org/10.5751/ES-03531-150314

Scott, J. 2000. Social network analysis: a handbook. Second edition. SAGE, London, UK.

SENPLADES (Secretaría Nacional de Planificación y Desarrollo). 2007. Plan Nacional de Desarrollo. SENPLADES, Quito, Ecuador.

Sewell, G. C. 2005. Actors, coalitions and the framework convention on climate change Dissertation. Massachusetts Institute of Technology, Cambridge, Massachusetts, USA.

Sosa, M. 2008. Water conflicts in the Chimborazo Province, Ecuador: the strategies of water users to claim and defend their water rights. Thesis. International Land and Water Management, Wageningen University, Wageningen, Netherlands.

Stanley, B. 2006. Learning to share the resource and the responsibility in an Andean watershed: demand for water threatens a unique ecological reserve in Ecuador. Case study: Comanagement of natural resources: local learning for poverty reduction. International Development Research Centre, Ottawa, Ontario, Canada.

Terán, J. F. 2007. Las quimeras y sus caminos: la gobernanza del agua y sus dispositivos para la producción de pobreza rural en los Andes ecuatorianos. CLACSO, Buenos Aires, Argentina.

Tockman, J., and J. Cameron. 2014. Indigenous autonomy and the contradictions of plurinationalism in Bolivia. Latin American Politics and Society 56(3):46-69. http://dx.doi.org/10.1111/ j.1548-2456.2014.00239.x

Tortajada, C. 2001. Institutions for integrated river basin management in Latin America. International Journal of Water Resources Development 17(3):289-301. http://dx.doi. org/10.1080/07900620120065084

Tulchin, J. S., and A. D. Selee, editors. 2004. Decentralization and democratic governance in Latin America. Woodrow Wilson International Center for Scholars, Latin American Program, Washington, D.C., USA.

Walker, B., C. S. Holling, S. R. Carpenter, and A. Kinzig. 2004. Resilience, adaptability and transformability in social-ecological systems. Ecology and society 9(2):5. http://dx.doi.org/10.5751/ ES-00650-090205

Wollmann, H. 2015. Public services provision in European countries: from public/municipal to private sector - and back to municipal? Pages 147-156 in A. Martinelli and C. He, editors. Globalmodernization review: new discoveries and theories revisited. World Scientific, Singapore. http://dx.doi.org/10.1142/97898146$\underline{160720017}$ 
Appendix 1.

Table A1.1. List of respondents

\begin{tabular}{|c|c|c|c|}
\hline Code & Partnership & Organization & Date \\
\hline E1 & \multirow{16}{*}{ Chambo } & UNACH & $10 / 23 / 15$ \\
\hline E4 & & GADP Chimborazo & $10 / 14 / 15$ \\
\hline E10 & & Interjuntas & $10 / 15 / 15$ \\
\hline E11 & & EMAPAR & $10 / 15 / 15$ \\
\hline E12 & & ESPOCH & $9 / 29 / 15$ \\
\hline E13 & & CESA & $9 / 29 / 15$ \\
\hline E14 & & INAMHI & $10 / 5 / 15$ \\
\hline E15 & & Ministry of Agriculture & $10 / 14 / 15$ \\
\hline E19 & & CONAGOPARE & $10 / 15 / 15$ \\
\hline \multirow[t]{2}{*}{ E20 } & & CESA & $10 / 15 / 15$ \\
\hline & & & $18 / 10-17$ \\
\hline \multirow[t]{2}{*}{ E28 } & & AVSF & $10 / 17 / 15$ \\
\hline & & & $19 / 10 / 17$ \\
\hline E18 & & Ministry of the Environment & $10 / 14 / 15$ \\
\hline \multirow[t]{2}{*}{ E26 } & & SENAGUA & $9 / 17 / 15$ \\
\hline & & & $19 / 10 / 17$ \\
\hline \multirow[t]{3}{*}{$\mathrm{E} 2$} & \multirow{8}{*}{ Machángara } & \multirow[t]{3}{*}{ University of Cuenca } & $8 / 18 / 16$ \\
\hline & & & $6 / 16 / 15$ \\
\hline & & & $10 / 10 / 17$ \\
\hline \multirow[t]{2}{*}{ E3 } & & \multirow[t]{2}{*}{ Machángara Board } & $9 / 30 / 16$ \\
\hline & & & $4 / 10 / 17$ \\
\hline E5 & & Ministry of Agriculture & $9 / 6 / 16$ \\
\hline \multirow[t]{2}{*}{ E6 } & & \multirow[t]{2}{*}{ ETAPA } & $6 / 16 / 15$ \\
\hline & & & $8 / 5 / 16$ \\
\hline
\end{tabular}




\begin{tabular}{|c|c|c|c|}
\hline & & & $10 / 12 / 17$ \\
\hline E7 & & SENAGUA & $12 / 1 / 16$ \\
\hline \multirow[t]{2}{*}{ E8 } & & \multirow[t]{2}{*}{ ELECAUSTRO } & $10 / 19 / 15$ \\
\hline & & & $8 / 1 / 16$ \\
\hline \multirow[t]{2}{*}{ E9 } & & \multirow[t]{2}{*}{ ETAPA } & $6 / 15 / 15$ \\
\hline & & & $8 / 5 / 16$ \\
\hline \multirow[t]{2}{*}{ E16 } & & \multirow[t]{2}{*}{ SENAGUA } & $6 / 18 / 15$ \\
\hline & & & $10 / 5 / 17$ \\
\hline E17 & & Machángara Board & $6 / 18 / 15$ \\
\hline E21 & & ELECAUSTRO & $10 / 18 / 17$ \\
\hline $\mathrm{E} 22$ & & Provincial Government of Azuay & $8 / 31 / 16$ \\
\hline $\mathrm{E} 23$ & & GAD Azuay & $10 / 26 / 15$ \\
\hline E24 & & Ministry of Agriculture & $5 / 10 / 17$ \\
\hline \multirow[t]{2}{*}{ E25 } & & \multirow[t]{2}{*}{ ETAPA } & $8 / 26 / 16$ \\
\hline & & & $3 / 10 / 17$ \\
\hline \multirow[t]{2}{*}{$\mathrm{E} 27$} & & \multirow[t]{2}{*}{ Ministry of the Environment } & $8 / 18 / 16$ \\
\hline & & & $10 / 21 / 17$ \\
\hline E29 & - & JP Chiquintad & $6 / 15 / 15$ \\
\hline E30 & - & Fundación Futuro Latinoamericano & $2 / 2 / 15$ \\
\hline E31 & - & SENAGUA & $20 / 09 / 18$ \\
\hline
\end{tabular}


Appendix 2. Survey Questionnaire 
El objetivo de este cuestionario es recopilar información sobre iniciativas de manejo colaborativo del agua existentes en Ecuador. La información proporcionada por Ud. será tratada como confidencial y será conocida solamente por el investigador y su equipo. Agradecemos su participación.

\section{Su nombre}

Organización a la que representa

\section{Consejo}

Fecha y hora 


\section{SECTION 1: CARACTERÍSTICAS DE LA ORGANIZACIÓN}

En esta sección queremos entender cómo es la participación de su organización en este consejo.

1. En qué año empezó su organización a trabajar en gestión del agua?

No sabe Y Usted?

2. En qué año se unió su organización al consejo? No Sabe Y Usted?

3. ¿Cuál es para Ud. el principal objetivo de este consejo?

4. Indique la frecuencia con la que su organización participa de las actividades de este consejo?

\begin{tabular}{|l|l|l|l|l|l|}
\hline & & & & \\
\hline A diario & Semanalmente & Mensualmente Semestralmente Anualmente No sabe
\end{tabular}


5. ¿Con qué frecuencia ha estado involucrada su organización en cada uno de los siguientes temas desde julio del 2015? Por favor coloque un número del 0 al $10(0$ = nada)

\begin{tabular}{|l|l|}
\hline $\begin{array}{l}\text { Buscando información sobre las nuevas regulaciones } \\
\text { sectoriales }\end{array}$ & \\
\hline Analizando información sobre las regulaciones & \\
\hline Preparando reportes sobre las regulaciones & \\
\hline Comunicando análisis sobre las regulaciones & \\
\hline Organizando reuniones para analizar las regulaciones & \\
\hline Buscando asesoría de expertos sobre las regulaciones & \\
\hline Contactando autoridades sobre las regulaciones & \\
\hline Construyendo capacidades en su organización & \\
\hline Evaluando las actividades pasadas del consejo & \\
\hline Otra A & \\
\hline Otra B & \\
\hline
\end{tabular}




\section{SECCIÓN 2. RELACIONES Y CONFIANZA}

6. La gestión del agua atrae a varios actores interesados en mejores resultados. Por favor haga una lista de las organizaciones con las que su organización ha trabajado en la gestión de esta cuenca desde Julio del 2015. Además, indique cómo Ud. percibe a cada uno de los actores según los criterios proporcionados.

\begin{tabular}{|c|c|c|c|c|c|}
\hline $\begin{array}{l}\text { Actor (indique los } \\
\text { nombres de las } \\
\text { organizaciones } \\
\text { abajo y asigne un } \\
\text { número de } \\
\text { acuerdo a cada } \\
\text { escala) }\end{array}$ & $\begin{array}{l}\text { Capacidad } \\
\text { Técnica } \\
0= \\
\text { completamente } \\
\text { incompetente } \\
10= \\
\text { completamente } \\
\text { competente }\end{array}$ & $\begin{array}{l}\text { Compromisos } \\
0=\text { nunca } \\
\text { cumple } \\
\text { compromisos } \\
10=\text { siempre } \\
\text { cumple } \\
\text { compromisos }\end{array}$ & 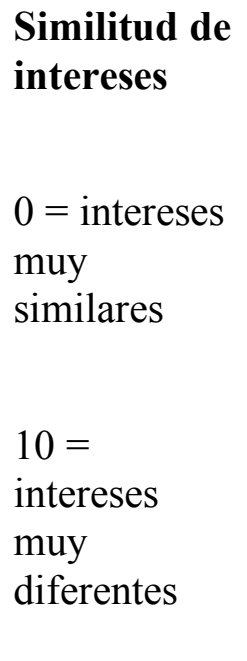 & $\begin{array}{l}\begin{array}{l}\text { Frecuencia } \\
\text { de } \\
\text { interacción }\end{array} \\
\text { Diaria } \\
\text { Semanal } \\
\text { Mensual } \\
\text { Semestral } \\
\text { Anual }\end{array}$ & $\begin{array}{l}\text { Influencia } \\
\text { Marque con } \\
\text { una X las } 3 \\
\text { organizacion } \\
\text { es más } \\
\text { influyentes } \\
\text { en la cuenca }\end{array}$ \\
\hline & & & & & \\
\hline & & & & & \\
\hline & & & & & \\
\hline & & & & & \\
\hline & & & & & \\
\hline & & & & & \\
\hline & & & & & \\
\hline & & & & & \\
\hline
\end{tabular}




\section{SECCIÓN 3. LEGITIMIDAD}

7. ¿Qué tan de acuerdo está con los siguientes enunciados? Piense solo en esta cuenca y marque la opción más adecuada.

\begin{tabular}{|c|c|c|c|c|c|}
\hline & $\begin{array}{l}\text { Completamente } \\
\text { de acuerdo }\end{array}$ & $\begin{array}{l}\text { De } \\
\text { acuerdo }\end{array}$ & $\begin{array}{l}\text { Ni de } \\
\text { acuerdo ni } \\
\text { en } \\
\text { desacuerdo }\end{array}$ & $\begin{array}{l}\text { En } \\
\text { desacuerdo }\end{array}$ & $\begin{array}{l}\text { Completamente } \\
\text { en desacuerdo }\end{array}$ \\
\hline $\begin{array}{l}\text { A. La composición actual del consejo representa } \\
\text { adecuadamente los intereses existentes en la } \\
\text { cuenca }\end{array}$ & & & & & \\
\hline $\begin{array}{l}\text { B. Los coordinadores o facilitadores del consejo } \\
\text { motivan a nuevos actores a participar }\end{array}$ & & & & & \\
\hline $\begin{array}{l}\text { C. Los intereses de su organización son } \\
\text { adecuadamente considerados en el consejo }\end{array}$ & & & & & \\
\hline $\begin{array}{l}\text { D. Su organización recibe información } \\
\text { apropiada sobre el funcionamiento del } \\
\text { consejo }\end{array}$ & & & & & \\
\hline $\begin{array}{l}\text { E. El conocimiento que los miembros de su } \\
\text { organización tiene sobre la cuenca es } \\
\text { utilizado para tomar decisiones en este } \\
\text { consejo }\end{array}$ & & & & & \\
\hline $\begin{array}{l}\text { F. La participación de su organización en el } \\
\text { consejo produce algún impacto en la gestión } \\
\text { del agua en esta cuenca }\end{array}$ & & & & & \\
\hline
\end{tabular}




\section{SECTION 4. PERCEPCIÓN DE EFECTIVIDAD}

8. Por favor seleccione la opción que mejor describa su opinión para cada una de las siguientes frases

\begin{tabular}{|c|c|c|c|c|c|}
\hline & $\begin{array}{l}\text { Totalmente } \\
\text { de acuerdo }\end{array}$ & $\begin{array}{l}\text { De } \\
\text { acuerdo }\end{array}$ & $\begin{array}{l}\text { Ni acuerdo } \\
\text { ni } \\
\text { desacuerdo }\end{array}$ & $\begin{array}{l}\text { En } \\
\text { desacuerdo }\end{array}$ & $\begin{array}{l}\text { Totalmente } \\
\text { en } \\
\text { desacuerdo }\end{array}$ \\
\hline \multicolumn{6}{|c|}{$\begin{array}{l}\text { A. Los beneficios que su organización recibe son mayores que las } \\
\text { contribuciones que hace al consejo }\end{array}$} \\
\hline \multicolumn{6}{|c|}{$\begin{array}{l}\text { B. Los miembros del consejo actúan en general de acuerdo a las } \\
\text { decisiones tomadas en la misma }\end{array}$} \\
\hline \multicolumn{6}{|l|}{$\begin{array}{l}\text { C. Los miembros respetan los compromisos adquiridos en el } \\
\text { consejo }\end{array}$} \\
\hline \multicolumn{6}{|l|}{ D. El consejo es capaz de resolver conflictos entre miembros } \\
\hline E. La distribución de costos que hace el consejo es justa & & & & & \\
\hline
\end{tabular}




\section{SECTION 5. RELACIONES CON OTRAS REDES}

9. Indique los nombres de otras iniciativas colaborativas para el manejo del agua (fondos de agua, consejos, proyectos, programas, plataformas, organizaciones, asociaciones, federaciones) en las cuáles su organización participa.

1

2

3

4

5

6

7

8 
10. ¿Quién considera Ud. que debería participar de este cuestionario? Por favor indique la información de contacto de la persona en la tabla

\begin{tabular}{|l|l|l|l|}
\hline Nombre & Organización & Teléfono & Correo electrónico \\
\hline & & & \\
\hline & & & \\
\hline & & & \\
\hline & & & \\
\hline & & & \\
\hline & & & \\
\hline
\end{tabular}

